\title{
Yield and Growth Response of Maize Crop to Urea and Gibberellic Acid Potash Salt (Ga-K Salt) in Calcarious Soil
}

\author{
Hafeez Ur Rahim ${ }^{1 *}$, Sajjad Ahmad², Laiq Zada ${ }^{1}$, Zaid Khan², Muhammad Ayoub Khan ${ }^{3}$, Muhammad Haris ${ }^{1}$, Amin \\ Ullah $^{1}$, Usman $^{4}$
}

${ }^{1}$ Department of Soil and Environmental Sciences, The University of Agriculture Peshawar, Pakistan

${ }^{2}$ Department of Agronomy, The University of Agriculture Peshawar, Pakistan

${ }^{3}$ Department of Plant breeding and genetics, The University of Agriculture Peshawar, Pakistan

${ }^{4}$ Department of Agricultural Chemistry, The University of Agriculture, Pakistan

Submission: January 23, 2018; Published: March 29, 2018

"Corresponding author: Hafeez Ur Rahim, Department of Soil and Environmental Sciences, The University of Agriculture Peshawar, Pakistan, Email: hafeez.kalpani@aup.edu.pk

\begin{abstract}
A field experiment was conducted at Nuclear Institute of Food and Agriculture Peshawar (NIFA) during Kharif season 2015 to assess the yield and growth response of maize crop to urea and gibberellic acid potash salt (GA-K salt). The experiment was laid out in randomized complete

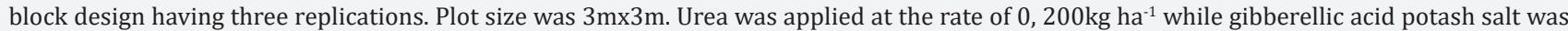
applied at the rate of $60 \mathrm{~g}$ ha- 1 in combination with $200 \mathrm{~kg} \mathrm{ha}^{-1}$. The gibberellic acid potash salt in combination with urea showed a maximum significant effect on the plant height, number of leaves per plant, leaf area, numbers of grains per year, thousand grain weight (g) and grain yield (kg ha-1), followed by urea alone while the minimum results was recorded from the control plots. From the overall experiment it is concluded that gibberellic acid potash salt in combination with urea showed a significant effect on the yield and growth of maize cropand should be recommended for farmers to use in the fields for his crops.
\end{abstract}

Keywords: Crops; Gibberellic acid; Plant development; Calcarious soil

\section{Introduction}

Maize (Zea Maize $L$ ) is an annual plant which belongs to family Gramineae and genus Zea. A Maize [1] (Zea Maize L) has a normal chromosome complements of 10 pairs. It is divided into 7 groups. The classification is based largely on the characters of kernels.

Maize [1] (Zea maize L) being the highest yielding cereal crop in the world is a significant importance for countries like Pakistan, where rapidly increasing population has already out stripped the available food supplies. In Pakistan, maize is the fourth largest grown crop after wheat, cotton and rice. The area under maize here is over one million hectares and production 3.5 million metric tons. Punjab contributes 39 per cent of the total area under maize and 30 percent of total production; KPK contributes 56 percent of the total area and 63 percent of the production while five per cent of the total area and three percent of the total production is contributed by Sindh and Baluchistan.

Maize [1] (Zea Maize $L$ ) has a variety of uses. Its grain is a rich source of starch 72\%, vitamins A \& B 3 to 5\%, proteins 10\%,
$4.8 \%$ oil, $5.8 \%$ fiber, $3.0 \%$ sugar and $1.7 \%$ ash. It is also a source of raw material for industry, where it is being extensively used for the preparation of corn starch, corn oil, dextrose, corn syrup, corn flakes, cosmetics, wax, alcohol and tanning material for leather industry.

Gibberellic acid which is also known as Gibberellin having various types including $\mathrm{A} 3, \mathrm{GA}$, and GA3, is a hormone which is present in plants and fungi. When purified, it is a white to paleyellow solid. According to studies by researchers in worldwide, 50 different Gibberellins types have been discovered, until now. Each one was determined by number over than 1 . The most famous gibberellin is "Gibberellic acid" which is present in majority of plants. Determined Gibberellin can be divided into 2 groups: C20 and C19 that first group has two carboxylic groups, without lactonic cycle, and the second one has one carboxylic and one lactonic cycle Alazemni and Ghorbanly.

Gibberellic acid is a simple gibberellin, a penta cyclicditerpene acid regulating growth and elongation of cells. 
It affects decomposition of plants and helps plants growth if used in small amounts, but eventually plants develop tolerance to it. Gibberellic acid is a very potent hormone whose natural occurrence in plants controls their development. Since GA regulates growth, applications of very low amount can have a profound effect while high amount will have the opposite effect. It is usually used in concentrations between 0.01 and $10 \mathrm{mg} / \mathrm{L}$ (Silva ALL). Gibberellins have a number of effects on plant development, they can stimulate rapid stem and root growth, induce mitotic division in the leaves of some plants, and increase seed germination Riley, John M, et al. Gibberellic Acid also increases the sink strength via increasing the length and growth rate of cells. Additionally, Gibberellic Acid regulators increase the strength of physiological source by increasing chlorophyll and effective age of leaves which finally lead to the increase of grain yield per area Vahid and Ghodrat et al. The application of Gibberellic acid increased growth, protein secretion and starch accumulation in maize endosperm suspension cells Cao and Co-workers. Gibberellins induce flowering in long-day plants which require chilling Harkess \& Lyons. Gibberellins are probably one of the growth regulators that have a significant effect on flowering [2]. Plant hormones such as gibberellin lead to a change, release or probably production of regulator protein and as a result, the active form of this protein is only found in Aleurone cells which have received the hormonal message Taiz and Zeiger. According to studies by researchers in worldwide, 50 different Gibberellins types were discovered, up to now and each have a specific effect on plant growth. The Current study and conducting an experiment is about the effect of Gibberellic acid potash salt (GAK-Salt) on the yield and growth of maize crop [3].

\section{Objective}

To investigate the growth response of Maize crop to Gibberellic Acid potash salt (GAK-Salt) in calcareous soil [4].

\section{Material and Methods}

A field experiment was conducted at Nuclear Institute of Food and Agriculture Peshawar (NIFA) during Kharif season 2015 to assess the yield and growth response of maize crop to urea and gibberellic acid potash salt in calcareous soil. The experiment was laid out in randomized complete block design with three replications. Plot size was $3 \mathrm{~m} \times 3 \mathrm{~m}\left(9 \mathrm{~m}^{2}\right)$. Two levels of urea was $\left(0,200 \mathrm{~kg} \mathrm{ha}^{-1}\right)$ and gibberellic acid was applied at the rate of $60 \mathrm{~g}$ ha- 1 in combination with urea to each treatment plot, the following parameters were observed [5-7].

\section{Treatments}
a. Control
b. Urea $\left(200 \mathrm{~kg} \mathrm{ha}^{-1}\right)$
c. GA-K salt $\left(60 \mathrm{~g} \mathrm{ha}^{-1}\right)+$ Urea $\left(200 \mathrm{~kg} \mathrm{ha}^{-1}\right)$

\section{Composite Soil Sampling}

Before sowing a composite soil sample was collected with the help of augur by using zigzag method up to $0-15 \mathrm{~cm}$ depth from different places in the field. After mixing $2 \mathrm{~kg}$ of sample was taken in plastic bags for laboratory analysis. The soil sample was analyzed for the Texture, Organic Matter, PH, EC, Lime, Bulk density and total nitrogen [8-11].

\section{Agronomic Parameters}

Yield and growth parameters which were under investigation:

a. Plant height

b. Number of Leaves plant ${ }^{-1}$

c. Mean single leaf area

d. Number of grains per ear

e. Thousand grain weight

f. Grain yield

\section{Plant height (cm)}

Ten Plants was randomly selected from each plot and its height $(\mathrm{cm})$ was recorded with inch tape.

\section{Number of leaves plant ${ }^{-1}$}

Five plants from each plot were randomly selected. Their leaves were counted and average to record the number of leaves per plant [12-14].

\section{Mean single leaf area}

Leaf area was calculated by measuring the lengths and widths of three middle leaves of five representative plants from each treatment. The mean single leaf area was calculated by using the following formula.

Leaf area $=$ Leaf length $\mathrm{x}$ Leaf width $\mathrm{x}$ Correction factor

\section{Number of grains ear-1}

To record the number of grains year-1, grains of five randomly selected ears in each plot were counted and then averaged.

\section{0 grain weight $(\mathrm{g})$}

A random sample of thousand grains will be taken from the grain yield of sub plot and will be weighed with an electronic balance to record weight for thousand grains.

\section{Grain yield (kg ha-1)}

Grains yield will be recorded after shelling of ears of two central rows from each plot and then dried and weight will be converted into $\mathrm{kg} \mathrm{ha}^{-1}$.

\section{Laboratory Work}

\section{Soil texture (Gee and Bahadur)}

A $50 \mathrm{~g}$ soil sample was taken in a conical flask and $10 \mathrm{ml}$ of $\mathrm{Na}_{2} \mathrm{CO}_{3}$ were added shake for a minute and pour the mixture to the $1 \mathrm{~L}$ cylinder. Put the hydrometer for $40 \mathrm{sec}$ reading and also note the temperature. Leave the cylinder for 2 hours reading after 2 hours by putting hydrometer in the cylinder and also note the temperature Koehler et al. 


\section{Soil pH (1:5) (Mc Lean)}

Soil $\mathrm{pH}$ was determined in 1:5 soil water suspensions by using PH meter (USDA Handbook 60 Richards).

\section{Soil EC (1:5) (Rhoades)}

The electrical conductivity was determined in 1:5 soil water suspensions by using EC meter (Rhoades, 1982).

\section{Organic matter (Nelson and Sommer)}

One gram of air dried soil was taken in a conical flask and $10 \mathrm{~mL}$ of $0.5 \mathrm{NK}_{2} \mathrm{Cr}_{2} \mathrm{O}_{7}$ and $20 \mathrm{~mL}$ of conc. $\mathrm{H}_{2} \mathrm{SO}_{4}$ was added to it. It was then allowed to stand for $30 \mathrm{~min}$ to complete the reaction. Later $200 \mathrm{~mL}$ of distilled water was added and the suspension was filtered. Ortho phenolphthalein Indicator, 2-3 drops was added to the filtrate. It was then titrated against $0.5 \mathrm{NFe}_{2} \mathrm{SO}_{4} \cdot 7 \mathrm{H}_{2} \mathrm{O}$ until the color changed to dark brown, indicating the end point. The percent organic matter was calculated using

$\% O M=\frac{\left[\left(m L o f K_{2} \mathrm{cr}_{2} \mathrm{O}_{7} \times N\right)-\left(\mathrm{mLofFeSO} \mathrm{F}_{4} \cdot 7 \mathrm{H}_{2} \mathrm{O} \times \mathrm{N}\right)\right]}{\text { Weightofsiol }} \times 0.69$

\section{Results and Discussion}

\section{Physiochemical characteristics of soil}

The soil was silt loam in texture, alkaline in reaction, calcareous in nature, low in soil organic matter content, poor in available $\mathrm{P}$ and total $\mathrm{N}$. Physical and Chemical properties of experiment are following in Table 1 [15-18].

Table1: Physiochemical characteristics of soil under investigations.

\begin{tabular}{|c|c|c|}
\hline Property & Units & Concentration \\
\hline Sand & $\%$ & 41.4 \\
\hline Silt & $\%$ & 51.4 \\
\hline Clay & $\%$ & 7.2 \\
\hline Textural class & - & Silt loam \\
\hline pH (1:5) & - & 7.61 \\
\hline Electrical conductivity(EC) & $\mathrm{d} \mathrm{Sm}^{-1}$ & 1.11 \\
\hline Lime & $\%$ & 15.3 \\
\hline Organic matter content & $\%$ & 0.96 \\
\hline Total nitrogen content & $\%$ & 0.1 \\
\hline Bulk density & $\mathrm{gm} \mathrm{cm}^{-3}$ & 1.37 \\
\hline
\end{tabular}

\section{Plant height}

Effect of urea alone and in combination with GA-K salt on plant height of maize crop is presented in Table 2. Mean values of the data showed that plant height was significantly $(\mathrm{P} \leq 0.05)$ affected by GA-K salt in combination with Urea. Maximum Plant height $233 \mathrm{~cm}$ was recorded with the combine application of GA-K salt and Urea followed by Urea alone $(199 \mathrm{~cm})$. The minimum plant height $(177 \mathrm{~cm})$ was recorded from the control. The possible reason for increase in plant height due to GA-K salt + Urea are that, Gibberellins increases the sink strength via increasing the length and growth rate of cell so thus increase in plant height occurs, these findings are in line with the findings of [19] Vahid Ghodrat et al Gibberellic acid stimulate rapid stem and root growth, induce mitotic division in the leaves of some plants, and increase seed germination so as a result increase in plant height was observed, these results are in line with Riley et al., Arif et al. reported significant increase in plant height of maize with application of nitrogen [20-23].

\section{Number of leaves plant ${ }^{-1}$}

Effect of urea alone and in combination with GAK- Slat on number of leaves per plant of maize crop is presented in Table 2. Means values of the data showed that number of leaves per plant was significantly $(\mathrm{P} \leq 0.05)$ affected by urea alone and in combination with GA-K salt. Highest number of leaves per plant 13 was recorded with the combine application of urea and GA-K salt, followed by Urea alone (12). The lowest number of leaves per plant 11 was recorded from the control. Gibberellic acid Increase the strength of physiological source by increasing chlorophyll and effective age of leaves. [19] Vahid Ghodrat et al. Gibberellic acid are extensively involved in all phase of plant growth and development. They promote leaf expansion, number of leaves per plant, flowering, and pollen, stem elongation, and seed development. The results are in accordance with the findings of the Monika Falkowska et al. But the Results are not in line with Kasem and Mesilhy who found that nitrogen increased number of leaves per plant [24-27].

\section{Leaf area}

Effect of urea alone and in combination with GA-K salt on leaf area of maize crop is presented in Table 2. Mean values of the data showed that leaf area was significantly $(\mathrm{P} \leq 0.05)$ affected by urea alone and in combination with GA-K salt. Larger Leaf area $422 \mathrm{~cm}^{2}$ was recorded with the combine application of application of urea and GA-K salt, followed by urea alone $\left(411 \mathrm{~cm}^{2}\right)$ was recorded. Minimum Leaf area $374 \mathrm{~cm}^{2}$ was recorded from control. The possible reason for increase in leaf area was due to GA-K salt + Urea is that, Gibberellic acids have a number of effects on plant development. They can stimulate rapid stem and root growth, induce mitotic division in the leaves of some plants, and increase seed germination Riley, John M.et al. Gibberellin produce centers in plants are: stem terminal, root active parts, young leaves, growing fruit and particularly, growing seeds. The results are in accordance with the findings of the Tavili et al.

\section{Number of grains per ear}

Number of grains per ear of maize crop as affected by urea alone and in combination with GA-K salt is presented in Table 2. Mean values of the data showed that number of grains per year was significantly $(\mathrm{P} \leq 0.05)$ affected by urea alone and in combination with GA-K salt. Maximum number of grains per year (471) was recorded with the combine application of urea and GAK-salt, followed by urea alone (391). While the minimum number of grains per year (335) was recorded from the control plot. Gibberellin can stimulate rapid stem and root growth, 
induce mitotic division in the leaves of some plants, and increase seed germination Riley, John M.et al. Gibberellin produce centers in plants are: stem terminal, root active parts, young leaves, growing fruit and particularly, growing seeds. The results are in accordance with the findings of the Tavili et al.

\section{Thousand grain weight (g)}

Table 2 shows thousand grain weight of maize crop as affected by urea alone and in combination with GA-K salt. Mean values of the data showed that thousand grain weights was significantly $(P \leq 0.05)$ affected by urea alone and in combination with GA-K salt. Maximum number of thousand grain weight (290g) was recorded with the combine application of urea and GA-K salt, followed by Urea alone (263g). The minimum thousand grain weight of $211 \mathrm{~g}$ was recorded from the control. Gibberellin can stimulate rapid stem and root growth, induce mitotic division in the leaves of some plants, and increase seed germination Riley, John M.et al. Gibberellin produce centers in plants are: stem terminal, root active parts, young leaves, growing fruit and particularly, growing seeds. The results are in accordance with the findings of the Tavili et al.

\section{Grain yield ( $\left.\mathrm{kg} \mathrm{ha}^{-1}\right)$}

Grain yield of maize crop as influenced by urea alone and in combination with GA-K salt is presented in Table 2. Mean values of the data showed that grain yield was significantly $(\mathrm{P} \leq 0.05)$ affected by urea alone and in combination with GA-K salt. Maximum number of grain yield $\left(5203 \mathrm{~kg} \mathrm{ha}^{-1}\right)$ was recorded with the combine application of GA-K salt and Urea followed by Urea alone $\left(4507 \mathrm{~kg} \mathrm{ha}^{-1}\right)$. The minimum grain yield $(3795 \mathrm{~kg}$ ha $^{-1}$ ) was recorded from the control. Gibberellin can stimulate rapid stem and root growth, induce mitotic division in the leaves of some plants, and increase seed germination and ultimately crop production Riley, John M et al. Gibberellin produce centers in plants are: stem terminal, root active parts, young leaves, growing fruit and particularly, growing seeds. The results are in accordance with the findings of the Tavili et al.

i: Means values of Plant height, Number of leaves plant ${ }^{-1}$, Leaf Area $\left(\mathrm{cm}^{2}\right)$, thousand grain weight $(\mathrm{g})$, no of grains per year, grain yield $\left(\mathrm{kg}^{-1}\right)$ influenced by Urea and Urea + Gibberellic acid potash salts in comparison to control.

\begin{tabular}{|c|c|c|c|}
\hline Parameters & Control & Urea(@200kg ha $\left.{ }^{-1}\right)$ & GA-K salt (60) \\
\hline Plant height $(\mathrm{cm})$ & $177 \mathrm{c}$ & $199 \mathrm{~b}$ & $233 \mathrm{a}$ \\
\hline No. of leaves & $11 \mathrm{a}$ & $12 \mathrm{a}$ & $13 \mathrm{a}$ \\
\hline Leaf Area $\left(\mathrm{cm}^{2}\right)$ & $374 \mathrm{c}$ & $411 \mathrm{ab}$ & $422 \mathrm{a}$ \\
\hline No of grains per ear & $335 \mathrm{c}$ & $391 \mathrm{~b}$ \\
\hline Thousand Grain weight $(\mathrm{g})$ & $211 \mathrm{c}$ & $263 \mathrm{~b}$ & $471 \mathrm{a}$ \\
\hline Grain yield $\left(\mathrm{kg} \mathrm{ha}^{-1}\right)$ & $3795 \mathrm{c}$ & $4507 \mathrm{~b}$ & $290 \mathrm{a}$ \\
\hline
\end{tabular}

\section{Conclusion and Recommendation}

From the overall experiment it is concluded that gibberellic acid potash salt showed a significant effect on the plant growth and development and showed maximum plant height, number of leaves per plant and Leaf area.

The Gibberellic acid potash salt $\left(60 \mathrm{gha}^{-1}\right)$ and urea $(200 \mathrm{~kg}$ ha $^{-1}$ ) should be recommended for farmers to use in the fields for his crops. Further research will be needed on the gibberellic acid potash salt in the future to obtained more accurate and desirable results.

\section{References}

1. Naghashzadeh M, Rafiee M, Khorgamy A (2009) Evaluation of effects of gibberellic acid on maize (Zea mays L.) in different planting dates. Plant Ecophysiology 3: 159-162.

2. Takahashi N, Phinney BO, Mac Millan J (1991) Gibberellins. SpringerVerlag, New York, USA.

3. Arif M, Ihsanullah, Sherin Khan, Gani F, Yousufzai HK (2001) Response of Maize Varieties to Different Planting methods 17(2): 159-163.

4. Pakistan Agriculture Research Council. All about Maize.

5. Daily times (2012) GM crops imperative to improve agri productivity.

6. Jabran K, Ata Z, Farooq M (2017) Model farming. Maize: cereal with a variety of uses.
7. Chandy KT Agricultural \& Environmental Education. Maize Inseda. Booklet Cereals \& Millets: Production: CMOS-3.

8. Jack G (2010) PivotIrrigationa-Create Healthy Cropsand Conserve Water.

9. Pioneer Corn Brochures.

10. Vitamins in corn.

11. Melis RJM, van Staden J, The Effect of Gibberellic Acid and Gibberellin Inhibitors on Cassava. Department of Crop Science and Department of Botany, respectively, University of Matal, Pietermaritzburg 3200, South Africa.

12. Eskandari S, Shokuhfar A (2015) Effect of different Gibberellic Acid hormone levels on yield and yield components of wheat cultivators. Indian Journal of Fundamental and Applied Life Sciences 5(S2): 14761483

13. Emongor V (2007) Gibberellic acid influence on vegetative growth, Nodulation, and yield of cowpea (Vigna unguiculatural) Journal of Agronomy 6(4): 509-517.

14. Afroz S, Firoz M, Shamsul H, Manzer HS (2005) Exogenous Application of Gibberellic Acid Counteracts the Ill Effect of Sodium Chloride in Mustard. Turk J Biol 29: 233-236.

15. Mehri S (2015) Investigating the effect of gibberellic acid and kinetin hormones on proline, protein and carbohydrates of leaf soluble in maize hybrids under drought stress. Cumhuriyet University Faculty of Science, Science Journal 36(3): 604-613. 
16. Pavlista AD, Baltensperger DD, Santra DK, Hergert GW, Knox S (2014) Gibberellic Acid Promotes Early Growth of Winter Wheat and Rye. American Journal of Plant Sciences 5(20): 2984-2996.

17. Ambika R, Senthilkumar G, Panneerselvam A, Sengottaian N (2015) Determination of Gibberellic acid from Rhizobium (maize) by thin layer Chromatography. World journal of pharmaceutical research 4(6) 967-973.

18. USDA (1997) Usual Planting and Harvesting Dates for US Field Crops. Agriculture Handbook \# 628, National Agricultural Statistics Services, Washington DC

19. Ghodrat V, Rousta MJ, Tadaion MS, Karampour A (2012) Yield and Yield Components of Corn (Zea mays L.) In Response to Foliar Application with Indole Butyric Acid and Gibberellic Acid. American-Eurasian J Agric \& Environ Sci 12(9): 1246-1251.

20. Schwartz HF, Brick MA, Harveson RM, Franc GD (2004) Dry Bean Production \& Integrated Pest Management. $2^{\text {nd }}$ edn, Colorado State University Regional Bulletin 562A, Fort Collins.

21. Pavlista AD, Santra DK (2013) Planting Winter Wheat in Dry Soil University of Nebraska NebGuide \#2211, Lincoln.

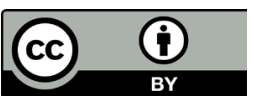

This work is licensed under Creative Commons Attribution 4.0 License DOI: 10.19080/JOJHA.2018.01.555558
22. Lyon DJ, Smith JA (2010) Wind Erosion and Its Control. University of Nebraska NebGuide \#1537, Lincoln.

23. Davies PJ (2010) Plant Hormones: Biosynthesis, Signal Transduction Action ( $3^{\text {rd }}$ edn), Springer-Verlag, New York, USA.

24. Pavlista AD, Santra DK, Schild JA, Hergert GW (2012) Gibberellic Acid Sensitivity among Common Bean Cultivars (Phaseolus vulgaris L) HortScience 47(5): 637-642.

25. Pavlista AD, Santra DK, Baltensperger DD (2013) Bioassay of Winter Wheat for Gibberellic Acid Sensitivity. American Journal of Plant Sciences 4: 2015-2022.

26. Busov VB, Brunner AM, Strauss SH (2008) Genes for Control of Plant Stature and Form. New Phytologist 177(3): 589-607.

27. Peng J, Richards DE, Hartley NM, Murphy GP, Devos KM, et al. (1999) "Green Revolution" Genes Encode Mutant Gibberellin Response Modulator. Nature 400(6741): 256-261.

\section{Your next submission with Juniper Publishers will reach you the below assets}

- Quality Editorial service

- Swift Peer Review

- Reprints availability

- E-prints Service

- Manuscript Podcast for convenient understanding

- Global attainment for your research

- Manuscript accessibility in different formats

( Pdf, E-pub, Full Text, Audio)

- Unceasing customer service

Track the below URL for one-step submission https://juniperpublishers.com/online-submission.php 